\title{
EFFECT OF IN-OVO NANO-SELENIUM INJECTION ON \\ HATCHABILITY, THYROID HORMONES AND HISTOLOGICAL CHANGES OF IMPROVED BALADI CHICKENS
}

Marwa M. Bahnas, Ali M. Abd El-Azim, Abdel-Azeem S. Abdel-Azeem, Kout Elkloub M. El. Moustafa, Abdel Karim M. Abdel Latif

\begin{abstract}
:
The current study amid to study the effect of in ovo injection by SeNPs on chicks weight, hatchability, thyroid hormones (T3 and T4) and histological parameters at the first day of the experiment of improved Baladi chicken.

A total number of 525 fertile improved Baladi eggs (Saso with Golden Montazah) with an average weight of $51.30 \mathrm{~g} \pm 0.81$ were used. Before incubation, eggs were randomly divided into seven groups. The first group was non-injected eggs, considered as control $\left(T_{1}\right)$, the second group was injected into air sac with sterile water with volume of $0.1 \mathrm{ml} / \mathrm{egg}\left(\mathrm{T}_{2}\right)$, the third group was only punctured $\left(\mathrm{T}_{3}\right)$ while the fourth $\left(T_{4}\right)$, fifth $\left(T_{5}\right)$, sixth $\left(T_{6}\right)$ and seventh $\left(T_{7}\right)$ groups were injected into air sac with $0.1 \mathrm{ml}$ sterile water containing $0.05,0.075,0.1$ and 0.2 $\mu \mathrm{g}$ SeNPs respectively. The eggs were incubated at normal condition of incubation.

Results obtained could be summarized as follows:

1- Hatching weight was significantly $(\mathrm{P} \leq 0.05)$ increased in treated groups compared to the control groups.

2- Hatchability of fertile eggs was significantly $(\mathrm{P} \leq 0.05)$ decreased by ovo injection with SeNPs as compared to the control.

3- Plasma T3 and T4 at the first day of age was significantly $(\mathrm{P} \leq 0.05)$ increased by ovo injection with SeNPs as compared to the control.

4- At hatch, there is no obvious histological difference in the studied organs such as liver, thymus, bursa and kidney except the thyroid gland in between the seven studied groups.
\end{abstract}

Key words: Nano, SeNPs, hatchability, thyroid hormones, histological structures. INTRODUCTION

The degree of response to in ovo feeding may depend on genetics, egg size, breeder hen age, and incubation conditions, site of injection and doses (Uni and Ferket 2003), however Some researchers who demonstrated that selenium sources help in increasing egg production traits as well as hatchability (Attia et al., 2010; Canogullari et al., 2010; Waseem et al., 2016).

Selenium has essential role in thyroid hormone metabolism, because it is necessary to convert the thyroxin (T4) to (T3) that means active form of this hormone. (Arthur et al., 1990), therefore Selenium is needed to synthesis type I iodothyronine deiodinase which stimulate conversion of T4 to T3 (Jianhua et al., 2000). Plasma T3 concentration is produced by 5'-deiodination of thyroxine the liver and kidney (Beckett et al., 1987).

No significant variation $(\mathrm{p}<0.05)$ occurred in chicks weight or the hatch weight of the chicks to eggs weight ratio and hatchability percent between the

Fayoum J. Agric. Res. \& Dev., Vol. 33, No.1, January, 2019 
Marwa M. Bahnas, et al.,

treatment groups (control and groups of nano form selenium) (Joshua et al. 2016). while Bakyaraj et al., (2012), reported that hatchability of $81.3 \%$ on in ovo feeding of selenium $0.3 \mu \mathrm{g}$. also, El Said (2015)reported that the hatch weight was significantly increased $(\mathrm{p}<0.05)$ by in-ovo injection with (SeNPs).

Nano, organic and inorganic selenium $(0.3 \mathrm{mg} / \mathrm{kg})$ improved plasma T3 concentration and reduced T4 in oxidative and non oxidative condition compared to the control (Boostani et al.(2014)).

T3 hormone increased as Se levels increased from 0.15 to $0.30 \mathrm{ppm}$ from 153 to $174 \mathrm{ng} / \mathrm{L}, 13.73 \%$ while using different sources of Se in broiler diets could not occurs any significant $(\mathrm{p} \leq 0.05)$ difference in $\mathrm{T} 3$ values at 40 days of age (Selim et al., 2015).

\section{MATERIALS AND METHODS}

A total number of 525 improved Baladi chicken fertile eggs with an average weight of $51 \mathrm{~g}$ were randomly divided into seven groups. The first group, was intact non-injected eggs, considered as control (C), the second group were injected into air cell with sterile water at concentration of $0.1 \mathrm{ml} / \mathrm{egg}$, the third group was only punctured and considered as sham injected group while the fourth , fifth, sixth and seventh groups were injected into air cell with $0.1 \mathrm{ml}$ water containing $(0.05 \mathrm{mg}, 0.075 \mathrm{mg}, 0.1 \mathrm{mg}$ and $0.2 \mathrm{mg}$ ) of SeNPs, respectively. Procedure was carried out at day 10 of embryonic development. The injection site was punctured by hard and thin stylus and the tested material was injected into the air cell of each egg by using graded insulin syringe (100 unit) then the punctured site was sealed with non-toxic wax stick.

The following measurements were recorded:

\section{Eggs weight:}

Eggs from each treatment were checked and weighted as average and recorded its weight

\section{Hatchability:}

At the end of 21 days of incubation period, Eggs from each treatment were checked and calculated hatchability\% by the following formula.

Hatchability $\%=($ Number of hatched chicks $/$ Number of fertile eggs $) \times 100$.

\section{Chicks weight:}

Hatching weight were individually recorded weekly.

The ratio of chicks weight for eggs weight:

The ratio was calculated according the following formula.

Chicks weight to eggs weight $=($ chicks weight $/$ eggs weight $) \times 100$.

\section{Thyroid hormones (T3 and T4):}

At hatch, individual blood samples, of about $1 \mathrm{ml}$, from randomly 42 birds ( 6 birds/treatment) were immediately taken during slaughtering into heparinized tubes.

Plasma were individually separated by centrifugation at $3000 \mathrm{rpm}$ for 10 minutes, transferred into a clean ependorf vials and stored in a deep freezer at approximately $-20{ }^{\circ} \mathrm{C}$ for later analysis.

Fayoum J. Agric. Res. \& Dev., Vol. 33, No.1, January, 2019 
Plasma constituents were determined calorimetrically, on individual bases, by using Spectrophotometer (model, GBC906 AA) and suitable commercial diagnostic kits (Stambio, San Antonio, Texas, USA) following the same steps as described by Sharp et al. (1981) for thyroid hormones $\left(\mathrm{T}_{3}\right.$ and $\left.\mathrm{T}_{4}\right)$.

\section{Statistical analysis:}

Analysis of variance of obtained data was computed using General Linear Model (GLM) procedure according to SPSS, 17.0 (2008). Significant differences among treatment means were evaluated using Duncan's multiple range test (Duncan, 1955).

\section{Histological structures:}

The livers, thyroid, thymus, spleen and bursa of fabricus of improved Baladi chicks from both sexes of the seven treatments have been included in this study. The body cavity was opened through a midventral incision, organs pieces (Approximately $0.5 \mathrm{~cm}^{3}$ ) were immediately dissected out, fixed in neutral buffered formalin $(10 \%)$ for $24 \mathrm{hrs}$, then dehydrated in ascending grades ethanol $(70 \%, 80 \%, 90 \%, 95 \%$ and $100 \%)$, cleared in 2 changes of xylene, embedded in paraffin wax and sectioned at $(5 \mu \mathrm{m})$ (Drury and Wallington,1983). The sections were stained for general histological purposes with Delafieds Haematoxylin and Eosin (HE). More than 10 digital images of every examined organ in randomly selected sight were made (in .jpg format, $3136 \times 2352$ pixels, 24 bit graphic pallet) with zoom 100, 200, 400 и 1000 on digital microscope Olympus BX45 at Nematology and Biotechnology lab, Faculty of Agriculture, Fayoum University, Egypt.

\section{RESULTS AND DISCUSSION}

\section{Hatchability, Chicks weight and ratio of chicks weight to eggs weight:}

The injection by SeNPs in ovo resulted in increase hatch weight of chicks compared by control groups where $0.1 \mathrm{mg}$ nano Se group recorded the highest value ( $38.35 \mathrm{~g})$ while the control group recorded the lowest value $(33.71 \mathrm{~g})$. Chicks weight to eggs weight ratio recorded 65.88, 70.53, 69.33, 71.80, 74.63, 75.46 and 36.80 respectively in groups $\mathrm{T}_{1}, \mathrm{~T}_{2}, \mathrm{~T}_{3}, \mathrm{~T}_{4}, \mathrm{~T}_{5}, \mathrm{~T}_{6}, \mathrm{~T}_{7}$, respectively. This finding is in accordance those reported with by $\boldsymbol{E l}$ Said (2015)who found that the hatch weight was significantly increased by in-ovo injection with (SeNPs) and disaccording with Joshua et al. (2016) who observed that Ovo feeding of broiler eggs with nano Se at graded levels on hatch weight of chicks and chicks weight to eggs weight ratio and hatchability percent showed no significant variation $(\mathrm{p}<0.05)$ occured in chicks weight, hatch weight, chicks to eggs weight ratio and hatchability percent.

The effects of in ovo injection by SeNPs on the hatchability are given in Table (1). A significant variation $(\mathrm{p} \leq 0.05)$ existed in the hatchability percent between the treatmentes (control and graded levels of nano form selenium, data showed a significant decreased in hatchability in SeNPs groups compared by control groups, which recorded $88,80,88,76,80,82$ and $78 \%$ in groups $\mathrm{T}_{1}, \mathrm{~T}_{2}$, $\mathrm{T}_{3}, \mathrm{~T}_{4}, \mathrm{~T}_{5}, \mathrm{~T}_{6}, \mathrm{~T}_{7}$, respectively. This finding is in Bakyaraj et al., (2012), who reported that hatchability of $81.3 \%$ on in ovo feeding of selenium $0.3 \mu \mathrm{g}$.

Fayoum J. Agric. Res. \& Dev., Vol. 33, No.1, January, 2019 
Marwa M. Bahnas, et al.,

however the degree of response to in ovo feeding may depend on genetics, egg size, breeder hen age, and incubation conditions (Uni and Ferket ,2003).

Thyroid hormones (T3 and T4):

The results of thyroid hormones in terms of triiodothyronine (T3) and thyroxine (T4) levels of improved Baladi chicks at the first day of age are shown in table (2). With regard to plasma T3 and T4 values, there was a significant response $(\mathrm{p} \leq 0.05)$ obtained for SeNPs levels among different treatments. The chicks of group 6 ( $0.1 \mathrm{mg}$ nano Se) had the highest T3 and T4 level compared to other treatments and control. Also, T3 and T4 levels were higher in all treated groups compared by control treatments. T3 values recorded 57.05, 57.50, 57.02, $66.95,70.62,93.22$ and $67.17 \mathrm{ng} / \mathrm{ml}$ in groups $\mathrm{T}_{1}, \mathrm{~T}_{2}, \mathrm{~T}_{3}, \mathrm{~T}_{4}, \mathrm{~T}_{5}, \mathrm{~T}_{6}, \mathrm{~T}_{7}$ respectively while $\mathrm{T} 4$ values recorded $3.87,3.75,3.75,4.45,4.90,6.17,4.57$ in groups $\mathrm{T}_{1}, \mathrm{~T}_{2}, \mathrm{~T}_{3}, \mathrm{~T}_{4}, \mathrm{~T}_{5}, \mathrm{~T}_{6}, \mathrm{~T}_{7}$ respectively. This results were in aggrement with Selim et al.(2015) who found that the specific values of thyroid T3 hormone showed increased values due to increasing supplemental Se levels from 0.15 to $0.30 \mathrm{ppm}$ from 153 to $174 \mathrm{ng} / \mathrm{L}, 13.73 \%$. Also, Boostani et al.(2014) found an increase in blood $\mathrm{T} 3$ concentration by nano, organic and inorganic selenium in oxidative and non oxidative condition, also Nano, organic and inorganic selenium $(0.3 \mathrm{mg} / \mathrm{kg})$ improve plasma T3 concentration and resucing T4 in oxidative and non oxidative condition compared to control group. Diets with various selenium source were significantly increasing $(\mathrm{p} \leq 0.05)$ plasma T3 concentration.

\section{Histological changes:}

At one day old, there is no obvious histological difference in the studied organs such as liver, thymus, bursa and spleen except the thyroid gland in between the seven studied groups.

\section{Thyroid:}

The follicles of the thyroid glands were lined by cuboidal or low columnar epithelium. In active follicle, the cells were mostly cuboidal or low columnar. In inactive follicles, the cells were squamous. The studied paraffin sections showed increased number of large sized follicles filled with colloidal secretory materials in all SeNPs treatments than those of the control except the in group $\mathrm{T}_{7}$ SeNPs (Figure 1) (Hodges, 1974).

Thymus:

Beneath the capsule a continuous layer of thymic epithelial cells is present, which essentially forms a blood-thymic barrier around blood vessels entering and leaving the capsule. Just underneath this epithelial layer is a thin subcapsular cortical region composed of precursor T-cells, called thymocytes, that are derived from bone marrow (or from yolk sac and fetal liver in embryonic stages). These are the most undifferentiated precursor T-cells (thymocytes) which progressively mature and differentiate into distinct $\mathrm{T}$-cell types. The thymic medulla contains fewer thymocytes than the cortex. The thymic epithelial cells are larger cells with pale cytoplasm and round to oval nuclei (Figure 2) (Hodges, 1974).

Fayoum J. Agric. Res. \& Dev., Vol. 33, No.1, January, 2019 


\section{Bursa of fabricius:}

Each bursal follicle was composed a peripheral cortex and a central medulla. A layer of undifferentiated epithelial cells occupied the periphery of the medulla, which was separated from the cortex by a capillary layer. The darkly stained cortex was composed of many closely packed small lymphocytes. The paler medulla contained fewer cells of various sizes (Figure, 3 ). The mucosal fold of the bursa was lined by pseudostratified columnar epithelium, except at the apex of each follicle, which was covered by a simple columnar epithelium. The populations of lymphocytes were uniformly distributed and the periphery of the medulla was smooth and regular in appearance in the follicles of chickens(Hodges, 1974).

\section{Liver:}

Histological examination of the liver samples of seven studied groups showed that the liver capsule body is clearly visible and composed of dense irregular connective tissue called Glisson`s capsule. The liver parenchyma of birds resemble the liver of mammalian but there is some different in histological features such as absent of lobules and interlobular trabeculae. The lobed structure of the liver is not clearly visible where the liver acinus has a classic look and anastomoses together forming blood lacunae with circulating blood. Around the lacunae and vascular connective trabeculae lymphoid follicles in the activation stage are located, characterized by a loose arrangement of cellular elements without clear structural framework (Figure, 4) (Hodges, 1974).

\section{Spleen:}

The spleen was a rounded, reddish-brown organ which lies close to the right side of the junction between the proventriculus and gizzard. It was a mixed lymphoid tissue, having both the $\mathrm{T}$ - and B-cell zones. The spleen surrounded by a thick splenic capsule and there was a small number of trabeculi. The red pulps were less distinct and these were scattered distributed within the white pulp. The white pulp was composed of network of reticular cells and reticular fibers within which small, medium and large sized lymphocytes and plasma cells were diffusely distributed. It contained sheathed arteries and lymphatic nodules. The red pulp of the spleen was formed from venous sinuses and anastomosing cord of reticular cells, macrophages, lymphocytes and blood cells. The network of the splenic tissue was consisted of a network of reticular cells and fibers (Figure, 5) (Hodges, 1974).

\section{CONCLUSION}

It could be concluded that ovo injection by SeNPs of improved Baladi chickens eggs may be a good way to improve chicks hatch weight and increasing thyroid hormones.

Fayoum J. Agric. Res. \& Dev., Vol. 33, No.1, January, 2019 
Table (1): Effect of in ovo injection by selenium nano particles (SeNPs) in post hatch on chicks weight (g), Chicks to eggs weight ratio and hatchability \% of improved Baladi chicken.

\begin{tabular}{|c|c|c|c|c|c|}
\hline \multicolumn{2}{|c|}{ TEST GROUPS } & Egg weight ( g ) & $\begin{array}{l}\text { Hatch Weight of } \\
\text { chicks ( g ) }\end{array}$ & $\begin{array}{c}\text { Chicks to eggs } \\
\text { weight ratio }\end{array}$ & Hatchability \% \\
\hline \multirow{3}{*}{$\begin{array}{c}\Omega \\
\stackrel{0}{0} \\
\stackrel{0}{0}\end{array}$} & $\mathbf{T}_{1}$ & 51.17 & $33.71^{\mathrm{f}}$ & $65.88^{\mathrm{d}}$ & $88.00^{\mathrm{a}}$ \\
\hline & $\mathbf{T}_{2}$ & 50.80 & $35.83^{\mathrm{cd}}$ & $70.53^{\mathrm{bc}}$ & $80.00^{\mathrm{c}}$ \\
\hline & $\mathbf{T}_{\mathbf{3}}$ & 51.06 & $35.40^{d}$ & $69.33^{c}$ & $88.00^{\mathrm{a}}$ \\
\hline \multirow{4}{*}{$\sum_{\tilde{n}}^{\mathscr{a}}$} & $\mathbf{T}_{4}$ & 52.78 & $37.90^{\mathrm{ab}}$ & $71.80^{b}$ & $76.00^{d}$ \\
\hline & $\mathbf{T}_{5}$ & 51.20 & $38.21^{\mathrm{a}}$ & $74.63^{\mathrm{a}}$ & $80.00^{\mathrm{c}}$ \\
\hline & $\mathbf{T}_{6}$ & 51.02 & $38.53^{a}$ & $75.46^{\mathrm{a}}$ & $82.60^{b}$ \\
\hline & $\mathbf{T}_{7}$ & 51.06 & $36.80^{b c}$ & $72.07^{b}$ & $78.60^{\mathrm{c}}$ \\
\hline \multicolumn{2}{|c|}{$\pm \mathbf{S E}$} & 0.31 & 0.35 & 0.21 & 0.22 \\
\hline
\end{tabular}

$a, \mathrm{~b}, \mathrm{c}, \mathrm{d}, \mathrm{f}$ Means in the same column with different superscripts are significantly different $(\mathrm{p} \leq 0.05) \mathrm{T}_{1}$ : control, $\mathrm{T}_{2}$ : control $\left(\mathrm{ddH}_{2} \mathrm{O}\right.$ injection), $\mathrm{T}_{3}$ : control (pitted), $\mathrm{T}_{4}: 0.05 \mathrm{mgSe} \mathrm{NP}, \mathrm{T}_{5}$ : $0.075 \mathrm{mgSe} N \mathrm{~N}, \mathrm{~T}_{6}: 0.1 \mathrm{mgSe} \mathrm{NP}, \mathrm{T}_{7}: 0.2 \mathrm{mgSe} \mathrm{NP}$.

Table (2): Effect of in ovo injection by selenium nano particles (SeNPs) in post hatch on $\mathrm{T} 3$ and $\mathrm{T} 4$ at the first day of age of improved Baladi chicken.

\begin{tabular}{|c|c|c|c|}
\hline \multicolumn{2}{|c|}{ Treatments } & T3 $(\mathbf{n g} / \mathbf{m l})$ & T4 $(\boldsymbol{u I U} / \mathbf{m l})$ \\
\hline \multirow{3}{*}{ Control } & $\mathbf{T}_{\mathbf{1}}$ & $57.05^{\mathrm{b}}$ & $3.87^{\mathrm{c}}$ \\
\cline { 2 - 4 } & $\mathbf{T}_{\mathbf{2}}$ & $57.50^{\mathrm{b}}$ & $3.75^{\mathrm{c}}$ \\
\cline { 2 - 4 } & $\mathbf{T}_{\mathbf{3}}$ & $57.02^{\mathrm{b}}$ & $3.75^{\mathrm{c}}$ \\
\hline \multirow{3}{*}{ SeNPs } & $\mathbf{T}_{\mathbf{4}}$ & $66.95^{\mathrm{b}}$ & $4.45^{\mathrm{bc}}$ \\
\cline { 2 - 4 } & $\mathbf{T}_{\mathbf{5}}$ & $70.62^{\mathrm{b}}$ & $4.90^{\mathrm{b}}$ \\
\cline { 2 - 4 } & $\mathbf{T}_{\mathbf{6}}$ & $93.22^{\mathrm{a}}$ & $6.17^{\mathrm{a}}$ \\
\cline { 2 - 4 } & $\mathbf{T}_{\mathbf{7}}$ & $67.17^{\mathrm{b}}$ & $4.57^{\mathrm{bc}}$ \\
\hline \multicolumn{2}{|c|}{$\mathbf{\text { ISE }}$} & $4.86^{\mathrm{y}}$ & 0.31 \\
\hline
\end{tabular}

$\mathrm{a}, \mathrm{b}, \mathrm{c}, \mathrm{d}, \mathrm{f}$ Means in the same column with different superscripts are significantly different $(\mathrm{p} \leq 0.05) \mathrm{T} 1$ : control, T2: control (ddH2O injection), T3: control (pitted), T4: 0.05 mgSe NP, T5: $0.075 \mathrm{mgSe}$ NP, T6: 0.1mgSe NP, T7: $0.2 \mathrm{mgSe}$ NP.

Fayoum J. Agric. Res. \& Dev., Vol. 33, No.1, January, 2019 
EFFECT OF IN-OVO NANO-SELENIUM INJECTION ON

Figure(1): Photomicrograph showing the histological structures of the thyroid gland in different groups (one day old).

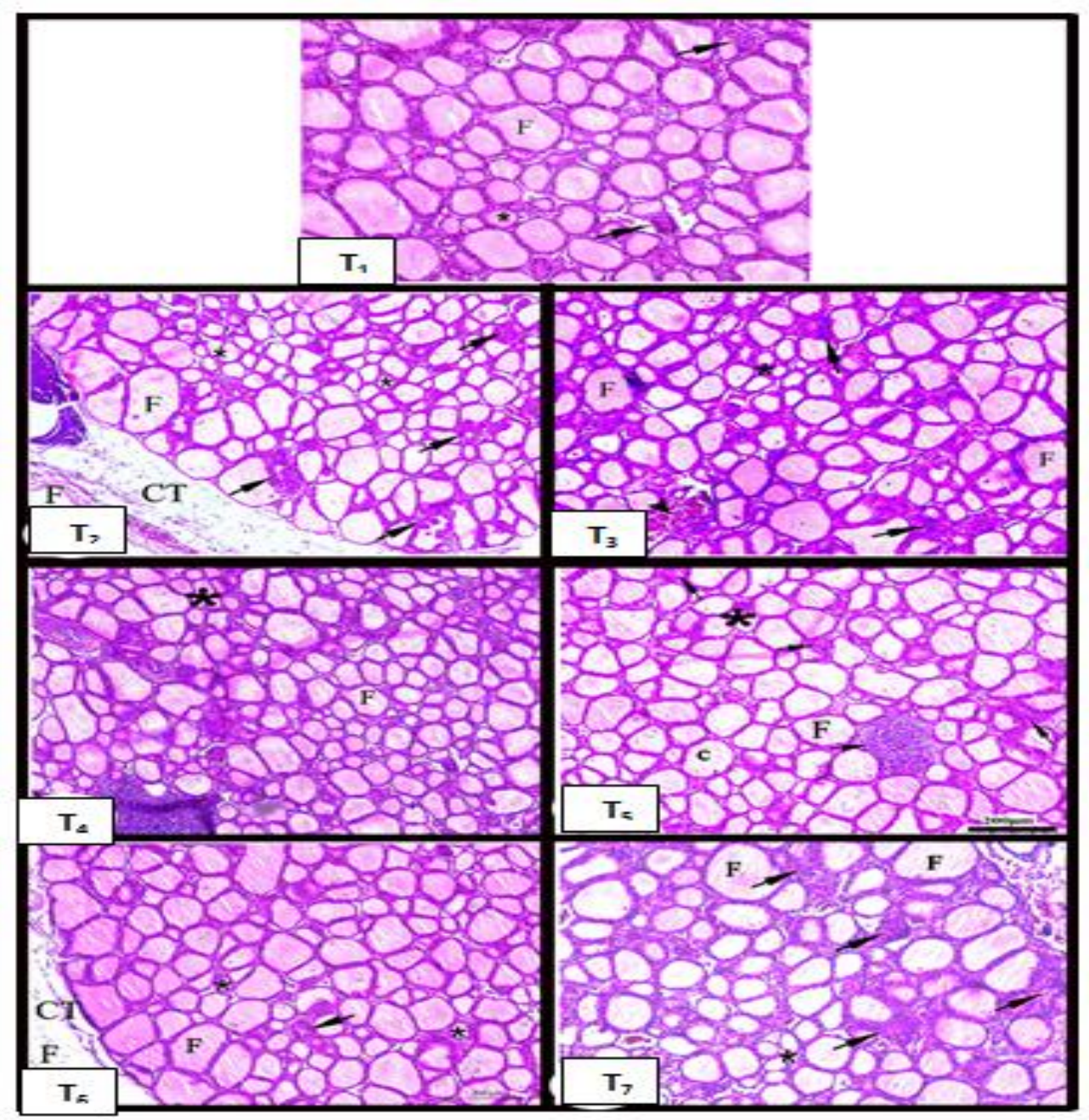

$\mathrm{T}_{1}$ : control, $\mathrm{T}_{2}$ : control (ddH $\mathrm{H}_{2} \mathrm{O}$ injection), $\mathrm{T}_{3}$ : control (pitted), $\mathrm{T}_{4}: 0.05 \mu \mathrm{Se} \mathrm{NP}, \mathrm{T}_{5}$ : $0.075 \mu \mathrm{gSe}$ NP, $\mathrm{T}_{6}: 0.1 \mu \mathrm{gSe} \mathrm{NP}, \mathrm{T}_{7}: 0.2 \mu \mathrm{gSe}$ NP. Note: Active and filled thyroid follicle $(\mathrm{F})$, lymphocyte infiltration (arrow), many small sized follicle $\left(^{*}\right)$ and connective tissue $(\mathrm{CT})$. Bar $=200 \mu \mathrm{m}$

Fayoum J. Agric. Res. \& Dev., Vol. 33, No.1, January, 2019 
Marwa M. Bahnas, et al.,

Figure (2): Photomicrograph showing the histological structures of the Thymus in different groups (one day old).

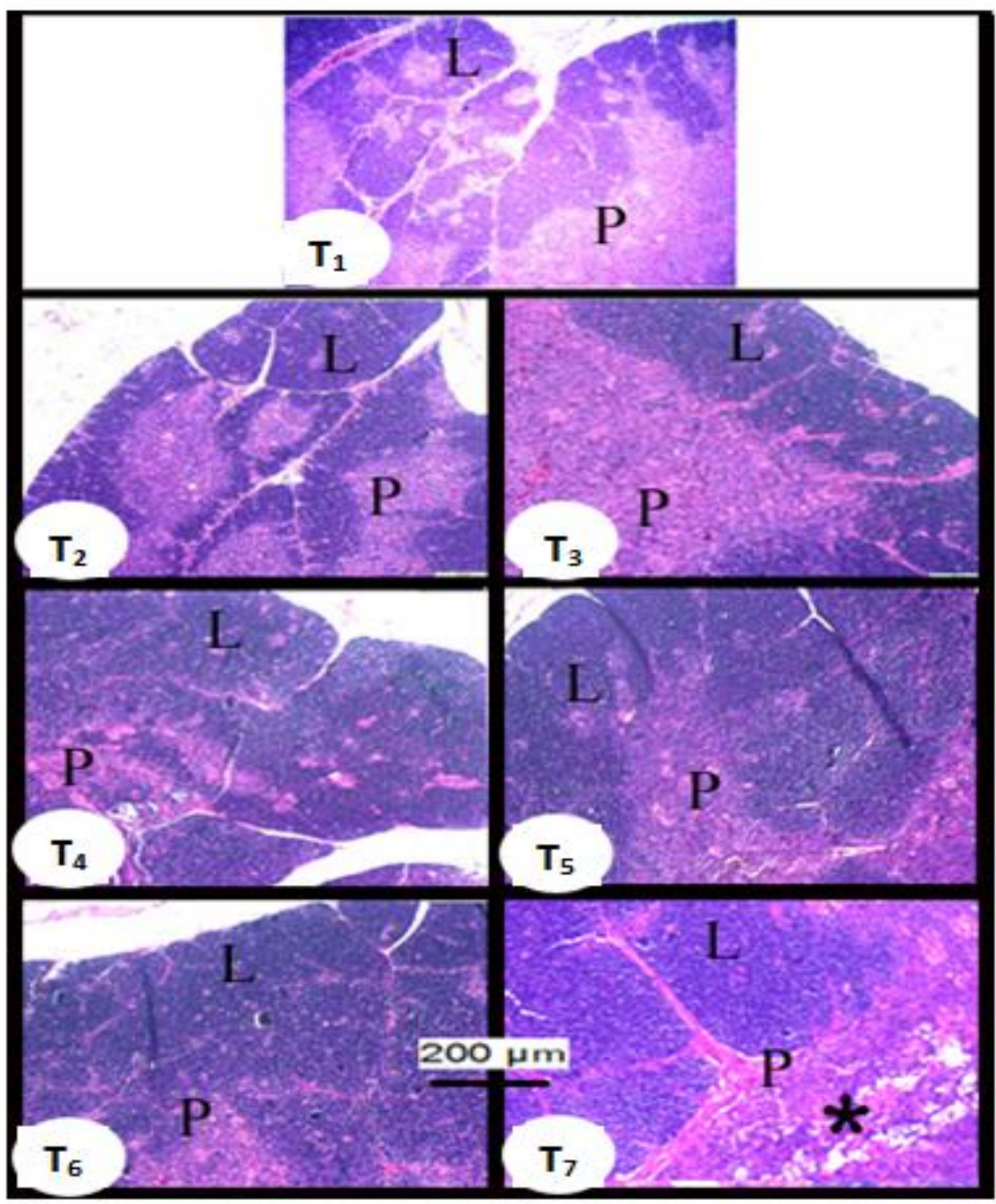

$\mathrm{T}_{1}$ : control, $\mathrm{T}_{2}$ : control ( $\mathrm{ddH}_{2} \mathrm{O}$ injection), $\mathrm{T}_{3}$ : control (pitted), $\mathrm{T}_{4}: 0.05 \mu \mathrm{Se} \mathrm{NP}, \mathrm{T}_{5}$ : $0.075 \mu \mathrm{gSe}$ NP, $\mathrm{T}_{6}: 0.1 \mu \mathrm{gSe} \mathrm{NP}, \mathrm{T}_{7}: 0.2 \mu \mathrm{gSe}$ NP., Note: the surrounded connective tissue capsule $(\mathrm{CT})$ and its septa surround the thymic lobes $(\mathrm{L})$ each one has darker cortex filled with T lymphocyte (l) more than the lighter medulla (P). Vacuolation, mild lymphocyte necrosis, and lymphocyte depletion were noted in the medulla of thymus in group T4. Bar $=200 \mu \mathrm{m}$

Fayoum J. Agric. Res. \& Dev., Vol. 33, No.1, January, 2019 
Figure (3): Photomicrograph showing the histological structures of the Bursa Fabricius in different groups (one day old).

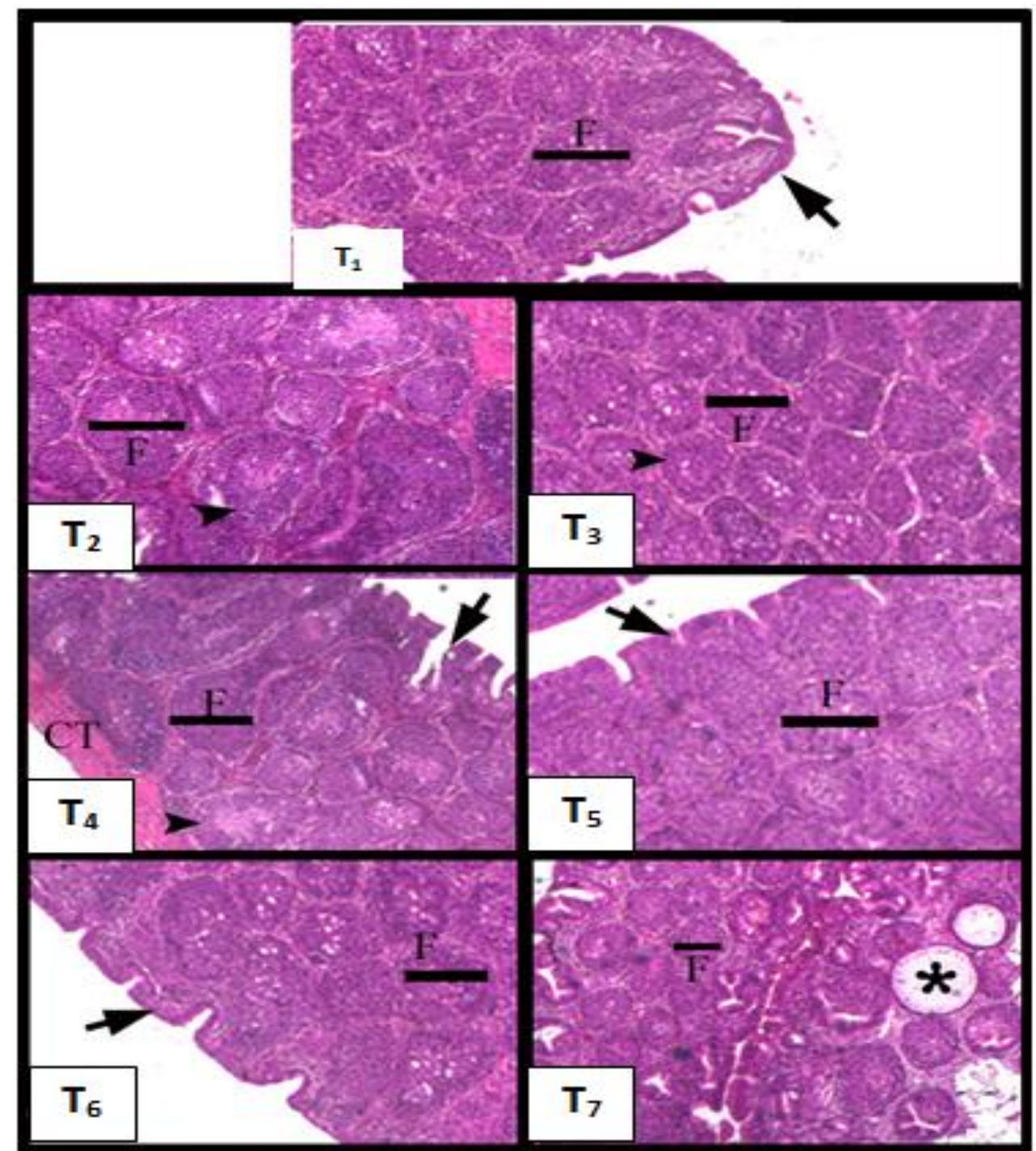

$\mathrm{T}_{1}$ : control, $\mathrm{T}_{2}$ : control ( $\mathrm{ddH}_{2} \mathrm{O}$ injection), $\mathrm{T}_{3}$ : control (pitted), $\mathrm{T}_{4}: 0.05 \mu \mathrm{Se} \mathrm{NP}, \mathrm{T}_{5}$ : $0.075 \mu \mathrm{gSe}$ NP, $\mathrm{T}_{6}: 0.1 \mu \mathrm{gSe}$ NP, $\mathrm{T}_{7}: 0.2 \mu \mathrm{gSe}$ NP., Note: Bursa follicle (arrowhead), each one consist of outer darker cortex (arrowhead) and lighter medulla, partial or completely degenerated follicles (*), pseudostratified columnar epithelium (arrow) and connective tissue $(\mathrm{CT})$. Bar $=200 \mu \mathrm{m}$

Fayoum J. Agric. Res. \& Dev., Vol. 33, No.1, January, 2019 
Marwa M. Bahnas, et al.,

Figure (4): Photomicrograph showing the histological structures of the spleen in different groups (one day old).

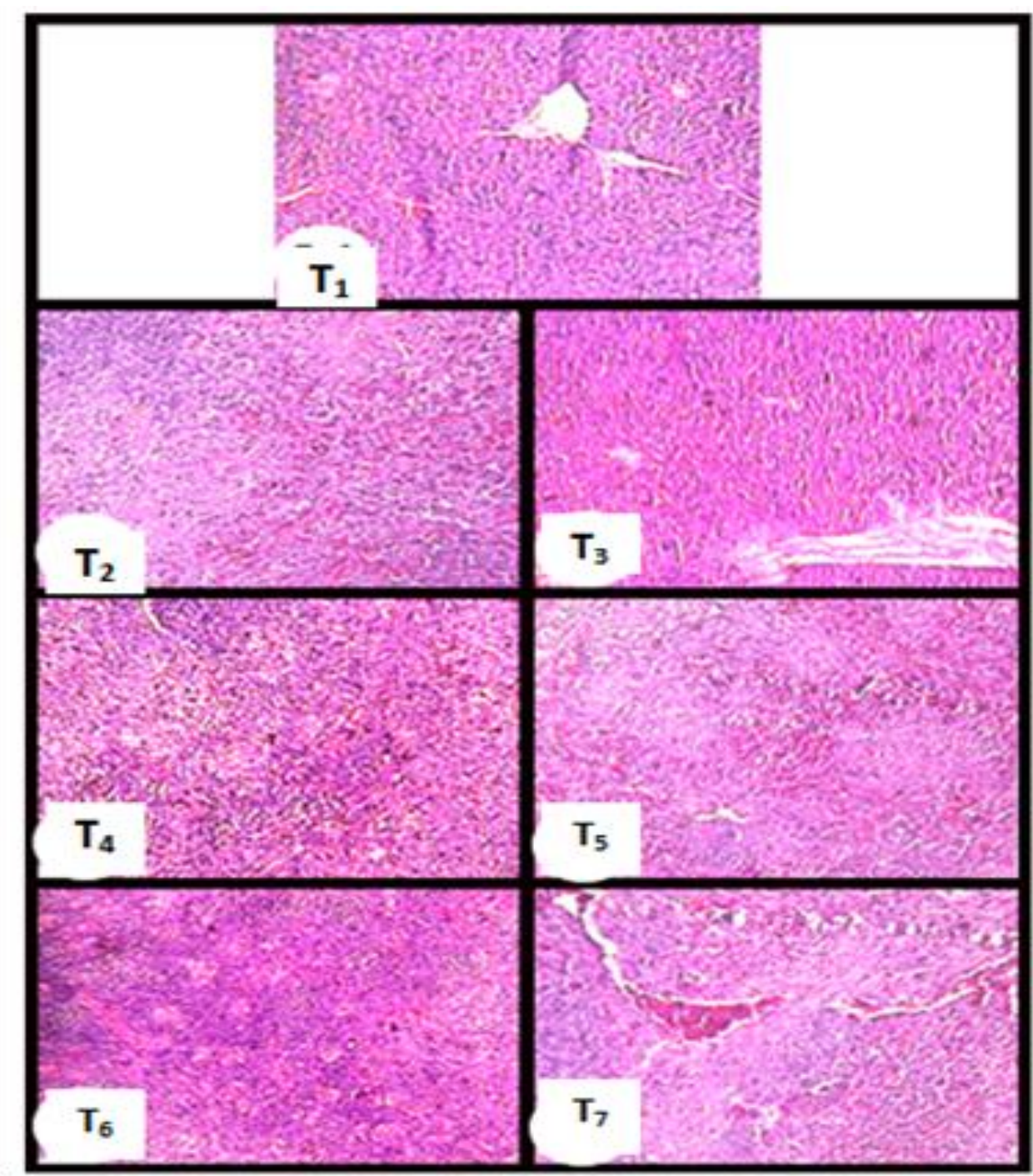

$\mathrm{T}_{1}$ : control, $\mathrm{T}_{2}$ : control (ddH $\mathrm{H}_{2} \mathrm{O}$ injection), $\mathrm{T}_{3}$ : control (pitted), $\mathrm{T}_{4}: 0.05 \mu \mathrm{Se} \mathrm{NP}$, $\mathrm{T}_{5}: 0.075 \mu \mathrm{gSe} N \mathrm{~N}, \mathrm{~T}_{6}: 0.1 \mu \mathrm{gSe}$ NP, $\mathrm{T}_{7}: 0.2 \mu \mathrm{gSe}$ NP. Bar $=200 \mu \mathrm{m}$

Fayoum J. Agric. Res. \& Dev., Vol. 33, No.1, January, 2019 
EFFECT OF IN-OVO NANO-SELENIUM INJECTION ON

Figure (5): Photomicrograph showing the histological structures of the liver in different groups (one day old).

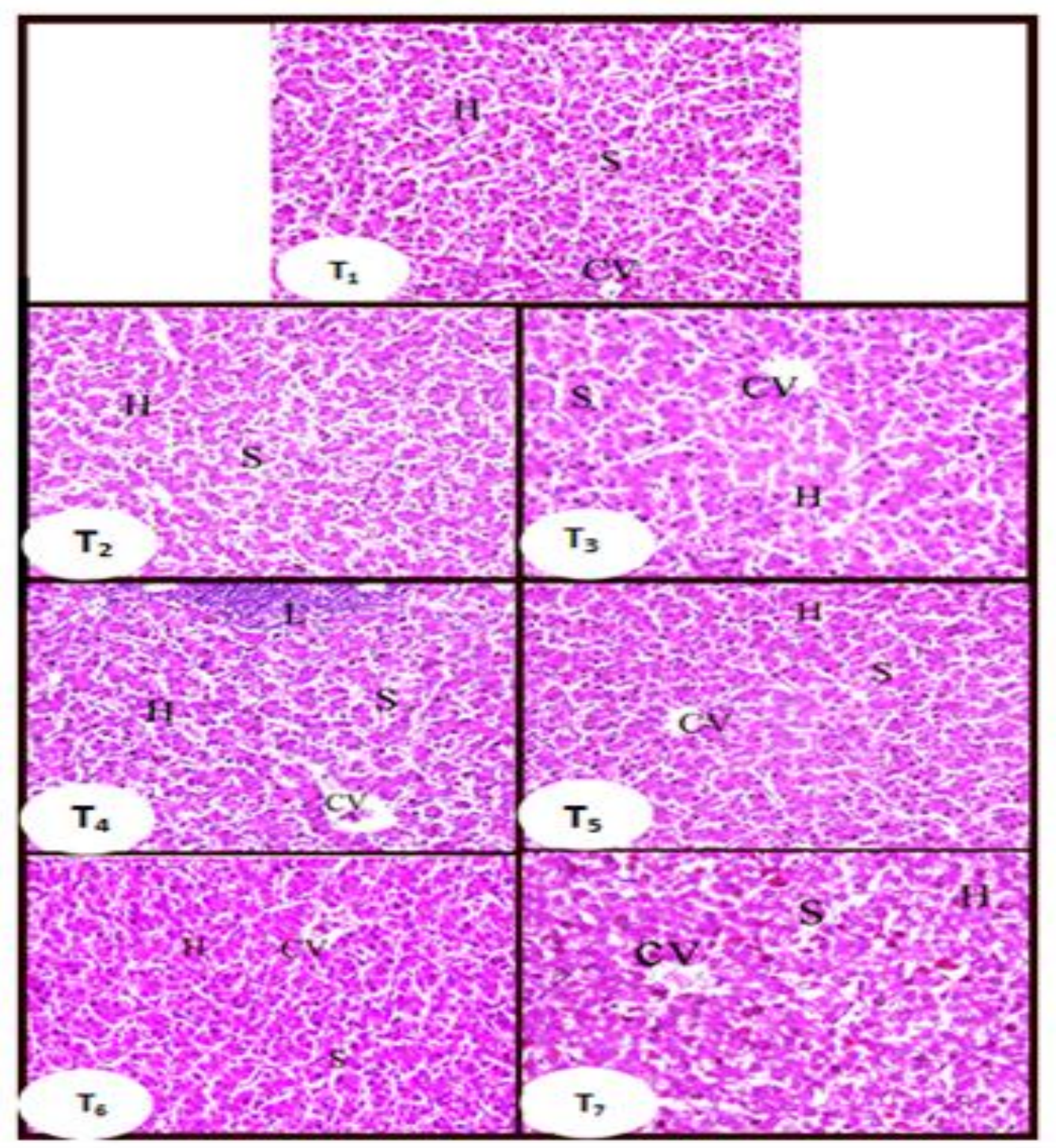

$\mathrm{T}_{1}$ : control, $\mathrm{T}_{2}$ : control (ddH $\mathrm{d}_{2} \mathrm{O}$ injection), $\mathrm{T}_{3}$ : control (pitted), $\mathrm{T}_{4}: 0.05 \mu \mathrm{Se} \mathrm{NP}, \mathrm{T}_{5}$ : $0.075 \mu \mathrm{gSe}$ NP, $\mathrm{T}_{6}: 0.1 \mu \mathrm{gSe}$ NP, $\mathrm{T}_{7}: 0.2 \mu \mathrm{gSe}$ NP. Note: Central vein (CV), hepatocyte $(\mathrm{H})$, blood sinusoid (S) blood cell (BC) and some hepatocytes with pyknotic nuclei (arrowhead) large necrotic area with red blood cell (BC) . Bar $=200 \mu \mathrm{m}$

Fayoum J. Agric. Res. \& Dev., Vol. 33, No.1, January, 2019 
References:

Arthur J.R., Nicol F. and Beckett G.J. (1990). Hepatic iodothyronine 5' deiodinase. The role of selenium. Biochemical Journal, 537-540.

Attia Y.A., Abdalah A.A., Zeweil H.S., Bovera F., Tag El-Din A.A. and Araft M.A. (2010): Effect of inorganic or organic selenium supplementation on productive performance, egg quality and some physiological traits of dual-purpose breeding hens. Czech Journal of Animal Science, 55, 505-519.

Bakyaraj S., Bhanja, S. K., Majumdar S. and Dash B.(2012). Modulation of post-hatch growth and immunity through in ovo supplemented nutrients in broiler chickens. Journal of the Science of Food and Agriculture, 92, 313-320.

Beckett G.J., Beddows S.E., Morrice P.C., Nicol F. and Arthur, J.R. (1987). Inhibition of hepatic deiodination of thyroxine is caused by selenium deficiency in rat. Biochemical Journal, 248, 443-447.

Boostani A., Sadeghi A.A., Chamani M. and Kashan N. (2014). The Effects of Organic, Inorganic and Nano-Selenium on Blood Thyroid Hormones Concentration in Broiler Chickens Exposed to Oxidative Stress. Life Science, 3, 146-149.

Canogullari S., Ayas T., Baylan M. and Copur G. (2010). The effect of organic selenium on performance characteristics, egg production parameters and egg selenium content of laying Japanese quail. Journal of the Faculty of Veterinary Medicine, Kafkas University, 743-749.

Drury R.A. and Wallington B.D.( 1983). fifth ed. Oxford University Press; New York:. Carleton's Histologcial Techniques.

Duncan D.B. (1955). Multiple ranges and multiple F-tests. Biometrics, 11, 1-42.

El Said, A. Eman. (2015). Influence of in-ovo injection with Nano particles Selenium (SeNPs) on growth performance, carcass yield and immune status of broiler chickens.Ph.D.Thesis.Faculty of Agriculture,Damietta University, 48-102.

Hodges R.D.(1974). The histology of the fowl. $2^{\text {nd }}$ Ed. Academic press.London.NY.

Jianhua H., Ohtsuka A. and Hayashi K. (2000). Selenium influences growth via thyroid hormone status in broiler chickens. British Journal of Nutrition, 84, 727-732

Joshua P. P., Valli C. and Balakrishnan V. (2016). Effect of in ovo supplementation of nano forms of zinc, copper, and selenium on posthatch performance of broiler chicken. Veterinary World, 9, 287-294.

Selim N.A., Radwan N. L., Youssef S. F., Salah Eldin T. A. and Abo Elwata S. (2015). Effect of inclusion inorganic, organic or nano selenium forms in broiler diets on: 2-Physiological, immunological and toxicity

Fayoum J. Agric. Res. \& Dev., Vol. 33, No.1, January, 2019 
statuses of broiler chicks. International Journal of Poultry Science 14, 144-155.

Sharp P.J., Van Tyem w.F., Van Middelkoop J.H., Klandorf H., Lea R.W., Shadwik A.(1981). Lack of relationship between concentration of plasma luteinizing hormone, thyroxine and prolactin at nine weeks of age and subsequent egg production in domestic hen. Br. Poultry Science. 22, 53-61.

SPSS (2008). Statistical software package for the social sciences. SPSS, Inc., Chicago, IL, USA.

Uni Z. and Ferket P.R. (2003).Enhancement of development of oviparous species by in ovo feeding. US Patent, 6, 592, 878.

Waseem M.Z., Anjum K., Saima N. and Jibran H. (2016). Egg quality, geometry and hatching traits of indigenous Aseel as influenced by organic and inorganic selenium supplementation. Indian Journal of Animal Research. doi:10.18805/ijar.9420.

Fayoum J. Agric. Res. \& Dev., Vol. 33, No.1, January, 2019 
تأثير حقن البيض بالنانوسيلنيوم على معدل الفقس ومعدلات هرمونات الغدة الدرقيه وبعض التغيرات

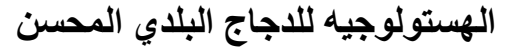

مروة م. بهنس*، علي م. عبد العظيم*، عبد العظيم س. عبد العظيم*، قوت القلوب م. مصطفى **، عبد

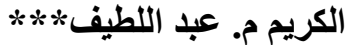

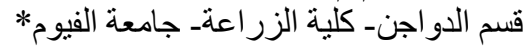

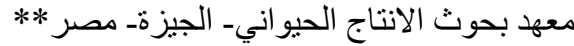

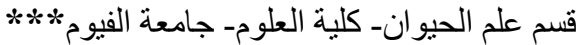

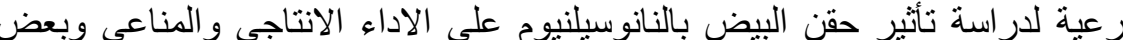

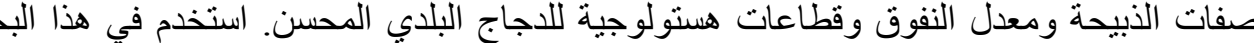

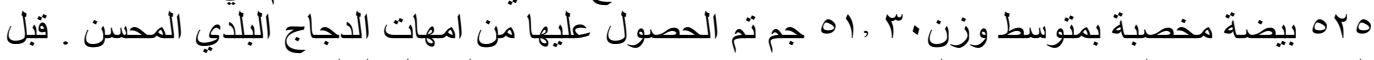

\begin{tabular}{|c|c|}
\hline نوع المعاملة & المجموعه \\
\hline الكنترول & $\mathbf{T}_{1}$ \\
\hline محقون بماء فقط & $\mathbf{T}_{2}$ \\
\hline مثقوب فقط & $\mathbf{T}_{3}$ \\
\hline 0 • . • ميكرو جم نانو سيلنيوم & $\mathbf{T}_{4}$ \\
\hline 0V •. • ميكرو جم نانوسيلنيوم & $\mathbf{T}_{5}$ \\
\hline 1. · ميكرو جم نانوسيلنيوم & $\mathbf{T}_{6}$ \\
\hline r. · ميكرو جم نانوسيلنيوم & $\mathbf{T}_{7}$ \\
\hline
\end{tabular}

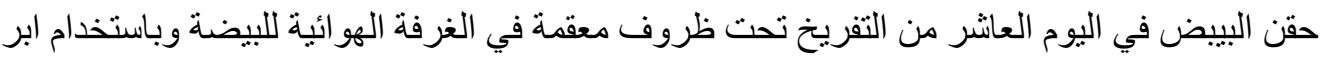

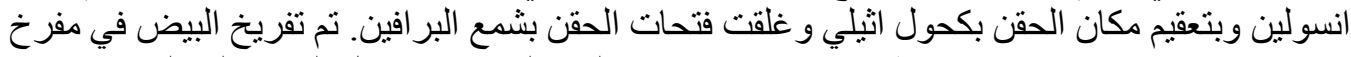

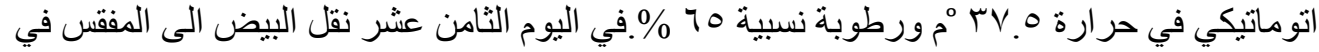

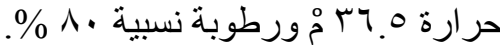
أهم النتائج المتحصل عليها :

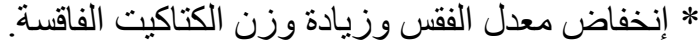

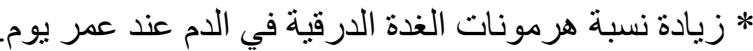

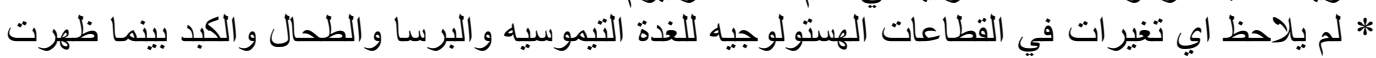

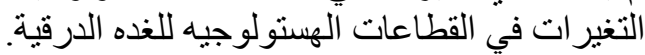

Fayoum J. Agric. Res. \& Dev., Vol. 33, No.1, January, 2019 